\title{
The Effect of Adolescent Pregnancy on Child Mortality in 46 Low- and Middle-Income Countries
}

\author{
Navideh Noori, Joshua L. Proctor, Yvette Efevbera, Assaf P. Oron
}

\author{
Navideh Noori*, Ph.D. \\ * Corresponding author \\ nnoori@,idmod.org, telephone: +1 (425) 528-0569
}

Institute for Disease Modeling, Global Health Division, Bill and Melinda Gates Foundation, 5005 th Ave N, Seattle, WA, USA, 98109.

Joshua L. Proctor, Ph.D.

Institute for Disease Modeling, Global Health Division, Bill and Melinda Gates Foundation, 5005 th Ave N, Seattle, WA, USA, 98109.

Yvette Efevbera, Sc.D.

Gender Equality Division, Bill and Melinda Gates Foundation, 500 5th Ave N, Seattle, WA, USA, 98109.

Assaf P. Oron, Ph.D.

Institute for Disease Modeling, Global Health Division, Bill and Melinda Gates Foundation, 500 5th Ave N, Seattle, WA, USA, 98109. 


\title{
The Effect of Adolescent Pregnancy on Child Mortality in 46 Low- and Middle-Income Countries
}

\author{
Navideh Noori ${ }^{1, *}$, Joshua L. Proctor ${ }^{1}$, Yvette Efevbera ${ }^{2}$, and Assaf P. Oron ${ }^{1}$ \\ ${ }^{1}$ Institute for Disease Modeling, Global Health Division, Bill and Melinda Gates Foundation, \\ Seattle, WA, USA \\ ${ }^{2}$ Gender Equality Division, Bill and Melinda Gates Foundation, Seattle, WA, USA \\ *Corresponding author, nnoori@idmod.org
}

\section{Background}

The World Health Organization (WHO) has highlighted the health risks to adolescent mothers and their children. Statements and reports typically group all mothers aged under 20 together. Some studies have examined the risk variations within this age group, and several child health outcomes have yet to be examined.

\section{Methods}

We analyzed data from Demographic and Health Surveys (DHS) collected between 2004 and 2018 in SubSaharan Africa (SSA) and South Asia, on children born to mothers 25 years old or younger. We examined the association between maternal age at first birth and deaths of neonates, infants, under 5 years old, and stillbirths, using mixed effects logistic regression and adjusting for common demographic and healthseeking variables.

\section{Findings}

The mortality rates at all early-life stages of children born to mothers aged $<16$ years, $16-17$ years, and 18 19 years at first birth were about 2-4 times, 1.5-2 times, and 1.2-1.3 times higher, respectively, than among children born to mothers aged 23-25 in both regions. Absolute mortality rates decreased over time, but the risk gradient versus age remained similar across time periods, regions, and most child mortality endpoints. After adjustment for rural/urban residence and maternal education, in SSA in 2014-2018 having a mother under 16 (10-15) years old was associated with stillbirth odds ratio (OR) 3.71 [95\% CI 2.50-5.51], neonatal mortality OR 1.92 [1.60-2.30], infant mortality OR 2.13 [1.85-2.46], and under-5 mortality OR 2.39 [2.132.68], compared with first children of mothers aged 23-25 years. For the same time period in South Asia ORs were stillbirths 5.12 [2.85-9.20], neonatal mortality 2.46 [2.03-2.97], infant mortality 2.62 [2.22$3.08]$, and under-5 mortality 2.59 [2.22-3.03]. Adjustment for additional risk factors did not affect the estimates substantially. 
medRxiv preprint doi: https://doi.org/10.1101/2021.06.10.21258227; this version posted June 12, 2021. The copyright holder for this preprint (which was not certified by peer review) is the author/funder, who has granted medRxiv a license to display the preprint in perpetuity.

It is made available under a CC-BY 4.0 International license .

\section{Interpretation}

Adolescent motherhood is associated with dramatically worse child survival, likely reflecting a combination of biological and social factors. Revising maternal age reporting conventions will help to highlight this burden. Targeted intervention strategies to eliminate underage pregnancy are warranted.

\section{Introduction}

Every year, about 12 million adolescent girls and young women aged 15-19 years and nearly a million adolescent girls under 15 years give birth. ${ }^{1}$ The majority of these births are in low- and middle-income countries (LMICs). ${ }^{2}$ The adolescent fertility rate (birth rate per 1,000 girls and young women aged 1519 years) over the period 2015-2020 was the highest in the Sub-Saharan Africa (SSA) region at 102.8 births per 1,000 person-years, far higher than the global average (44 per 1,000). ${ }^{3}$

Adolescence is a unique stage of human development and an important time for building the foundation of good health. Early childbearing can lead to devastating health consequences for the mother, since adolescents may not yet be physically ready for pregnancy or childbirth. ${ }^{3}$ Many adolescents experience complications during pregnancy and childbirth, which has become the leading global cause of death among 15-19 years old females. ${ }^{4}$ Several studies have associated early maternal age with neonatal and infant mortality, ${ }^{2,5,6,7}$ infant stunting, and preterm birth even after adjustment for socio-demographic factors, ${ }^{8}$ while in other studies controlling for a set of cofounders took away the maternal age effect. ${ }^{9}$ Because of these adverse outcomes, reduction of adolescent pregnancy has long been the focus of several organizations. For example, UNICEF and UNFPA have called for ensuring access to sexual and reproductive health, including for adolescent girls and young women (Target 3.7), and the elimination of child, early, and forced marriage (global indicators in the Sustainable Development Goals, Target 5.3), given their strong associations with early childbearing. ${ }^{5}$ Despite these efforts and the recent decline in overall adolescent mortality ${ }^{10}$ and global adolescent fertility rate, prevalence of adolescent pregnancies remains high and a major public health concern, especially in

\section{LMICs.}


medRxiv preprint doi: https://doi.org/10.1101/2021.06.10.21258227; this version posted June 12, 2021. The copyright holder for this preprint (which was not certified by peer review) is the author/funder, who has granted medRxiv a license to display the preprint in perpetuity.

It is made available under a CC-BY 4.0 International license .

In standard surveys, reports, and World Health Organization (WHO) statements, mothers under 20 are usually treated as a single group. ${ }^{11}$ However, adolescence represents a time of developmental transition, including physically, cognitively and psychologically, and there are substantial differences across the 10 to 19 years age range. ${ }^{12}$ Few studies have looked at the risk gradient versus age among young mothers. A meta-analysis of Demographic Health Surveys (DHS) has shown a higher risk of mortality to neonates born to mothers aged $<16$ and $16-17$ years old than neonates born to mothers aged 20-29 years in Sub-Saharan Africa (SSA) and South and Southeast Asia, ${ }^{2}$ even after adjusting for socio-economic, demographic and health service utilization variables. In LMICs, the infant mortality rate was higher among mothers with ages of 12-14 and 15-17 years than among older mothers. ${ }^{6}$ Finlay et $\mathrm{al}^{7}$ showed in a separate analysis that the risk of infant mortality in SSA is highest for high parity young mothers, and short birth intervals negatively affect infant mortality and stunting outcomes. A more recent study examined the association of maternal age, both young and advanced, on risk of neonatal mortality in LMICs using DHS data, and found the risk of mortality of neonates born to mothers aged $12-15$ and $45+$ years was higher than neonates born to mothers aged 25-29 years. ${ }^{13} \mathrm{~A}$ systematic review and meta-analysis in SSA found that most evidence was for mothers in the age group 15-19 years old, with very few studies providing data on adolescents aged $<18$, and concluded that there is a lack of high quality observational studies that adjust for sociodemographic factors. ${ }^{14}$

In this study, the most comprehensive of its kind to date, we have investigated the potential impacts of adolescent pregnancy on a substantially broader scope than previous studies, examining child mortality endpoints from stillbirths to under- 5 mortality, quantifying the risk gradient as a function of age from adolescence through young adulthood, and analyzing the effects of sociodemographic and health-seeking variables. We focused on SSA, the region with the highest adolescent pregnancy and child mortality burdens, as well as South Asia, the second-highest region in child mortality burden where adolescent pregnancy rates fell rapidly in recent years. 
medRxiv preprint doi: https://doi.org/10.1101/2021.06.10.21258227; this version posted June 12, 2021. The copyright holder for this preprint (which was not certified by peer review) is the author/funder, who has granted medRxiv a license to display the preprint in perpetuity.

It is made available under a CC-BY 4.0 International license .

\section{Methods}

\section{Data Source}

We analyzed DHS data collected between 2004 and 2018 from countries in SSA and South Asia. DHS are cross-sectional nationally representative large-scale household surveys that collect and analyze demographic, health, and nutrition data, in a manner that enables comparisons across countries and over time..$^{15}$ The women's questionnaire, used in this study, invites all women aged 15-49 in a surveyed household to respond. In a few surveys, the target group was women and girls aged 10-49 years old. We defined three time periods: 2004-2008, 2009-2013, and 2014-2018, to assess the variation in each outcome over time. We estimated the risk gradient versus age at first birth among adolescent mothers. Considering that the vast majority of first births in the two regions take place by the mothers' mid-20s, we restricted the analysis to mothers 25 years old or younger. In total, 35 countries with 80 surveys in SSA and 11 countries with 27 surveys in South Asia were included in the analysis (Supplementary Material).

\section{Endpoints and Risk Factors}

Maternal age at first birth within the ten years preceding the survey was divided into five groups: $<16$, 16-17, 18-19, 20-22, and 23-25 years old. For stillbirth, DHS only collects data from the five years preceding the survey. The age group $<16$ includes mothers aged $10-15$ years old, or 15 years old in surveys restricted to women aged 15-49. Risk factors accounted for in this analysis are sociodemographic factors: urban/rural residency and maternal education status (dichotomized as any education vs. none); economic factors: wealth quintile (a country-specific measure of the household wealth compared to other households in each survey and grouped as poorest, poorer/middle/richer, and richest in our analysis); and health-seeking factors: place of delivery (at home vs. health facility) and antenatal care (ANC) utilization (no ANC visit vs. any ANC visit). All risk factors were coded as categorical variables in our analysis.

We examined the following outcomes in our study: stillbirth (pregnancies that lasted seven or more months and terminated in fetal death), neonatal mortality (death after a live birth within the first 28 
medRxiv preprint doi: https://doi.org/10.1101/2021.06.10.21258227; this version posted June 12, 2021. The copyright holder for this preprint (which was not certified by peer review) is the author/funder, who has granted medRxiv a license to display the preprint in perpetuity.

It is made available under a CC-BY 4.0 International license .

days of life), infant mortality (death within the first year of life), child mortality (death after the first year and before reaching the age of five years), 1-59 month mortality (death after the first month and before reaching the age of five years), and under-5 mortality (death before reaching the age of five years). Of these, stillbirths, neonatal, infant and under-5 mortality are reported in the main article, and the remaining endpoints in Supplementary Material.

\section{Statistical Analysis}

Descriptive analyses included calculating the neonatal, infant, child, and under-5 and 1-59 month mortality rates and their sampling errors based on the DHS mortality rates estimation methodology, a synthetic cohort life table. ${ }^{16} \mathrm{We}$ calculated the mortality rates for three time periods in each region and for each maternal age group combined with selected risk factors. Among multiple births (twins, triplets, etc.), only those with the birth assigned order number of 1 by DHS were considered in the analysis. While excluding the remaining multiple-birth siblings reduces the sample size by a fraction of a percent, it helps simplify and stabilize the analysis by avoiding the need to account for another level of dependence.

A mixed effect logistic regression model was applied to each time period and each region separately, to examine the association between each of the outcome variables and the risk factors. A model including only age group and the random effects was developed, called here Model 0 . The model was further adjusted for different combinations of risk factors, based on prior knowledge of common risk factors for LMIC child mortality, as well as to assess the impact of leading healthcare access and socioeconomic indicators on the risk gradient. In Model 1, maternal age at first birth, urban/rural residency, and maternal education status were included. Questions about place of delivery and antenatal care utilization were available for the last births in the three/five years preceding the survey. A model adjusting for maternal age and healthcare accessibility factors was developed, called here Model 2. Given that the Primary sampling units (PSUs), year of survey, and country name were used as nested random effects in the model, the wealth index represents the deviation of household wealth from its own country's mean wealth ${ }^{6}$ and Model 1 was further adjusted for the wealth index, called 
medRxiv preprint doi: https://doi.org/10.1101/2021.06.10.21258227; this version posted June 12, 2021. The copyright holder for this preprint (which was not certified by peer review) is the author/funder, who has granted medRxiv a license to display the preprint in perpetuity.

It is made available under a CC-BY 4.0 International license .

here Model 3. We also combined the two health care variables into one and grouped the outcomes as having either ANC visit or facility birth; both ANC visit and facility birth; and no ANC visit and home delivery, and further adjusted Model 1 for this variable, called here Model 4. Note that despite including Model 1's variables, Model 4 is not nested within Model 1 as reported here, because the health-seeking variables were only available for each mother's last birth. Together with the first-birth constraint of all models, this reduces the sample size by $5-7 \mathrm{x}$, as well as weights the sample more towards recent first births. Models 0-2 are reported in the main article, and Models 3 and 4 in the supplementary material. Each survey's sample weights were used as the model prior weights in the fitting process. Mothers of age 23-25 years old were considered the reference age group. All the analyses were performed in $\mathrm{R} 4.0 .^{17}$

\section{Results}

\section{Univariate Maternal-Age Risk Gradient}

The number of first births and neonatal, infant, child, and under-5 deaths to women aged under 25 years old that occurred within ten years preceding the survey, grouped by region, survey period, and age, are given in eTables 1 and 2 in the supplement. Within each time period, about $20-23 \%$ of first births to mothers 25 years old or younger in SSA were attributed to mothers under 18 years old. In South Asia, this proportion was lower and decreased from 2004-2008 (15.7\%) to 2014-2018 (8.1\%).

The majority of women across all ages and time periods lived in rural areas. Most were either married or in union with a man, and about $63 \%$ and $36 \%$ of mothers aged under 16 had never used any contraceptive method in SSA and South Asia, respectively. About $60 \%$ and $43 \%$ of mothers aged $<16$ years old respectively, in SSA and South Asia, in the 2004-2008 period had no formal education. This value decreased with age and time in SSA, but a similar trend was not observed in survey data from South Asia (eTable 2). In both regions, about $80 \%$ women had at least one antenatal care visit. About $45 \%$ to $48 \%$ of pregnant women aged $<16$ years old in both regions gave birth at home during the 2014-2018 period, 2-3 times more often than mothers over 20 years old (eTables 1 and 2). 
medRxiv preprint doi: https://doi.org/10.1101/2021.06.10.21258227; this version posted June 12, 2021. The copyright holder for this preprint (which was not certified by peer review) is the author/funder, who has granted medRxiv a license to display the preprint in perpetuity.

It is made available under a CC-BY 4.0 International license .

The mortality rates for different child outcomes and their sampling errors are given in Table 1 for SSA and South Asia and eTables 3 and 4, respectively. In SSA, neonates, infants and children under-5 born to mothers aged $<16$ were at about two times higher risk of death $(54 \cdot 5 \pm 4 \cdot 5,95 \cdot 9 \pm 5 \cdot 5$ and $156 \cdot 5 \pm 6 \cdot 6$ deaths per 1000 live births, respectively, in 2014-2018) than those born to mothers aged 23-25 years old $(28 \pm 1 \cdot 6,44 \cdot 5 \pm 1 \cdot 9$ and $64 \cdot 8 \pm 2 \cdot 4$, respectively). The mortality rates for children of the $<16$ age group in South Asia were two to three times higher $(59 \cdot 7 \pm 15,84 \cdot 4 \pm 20.8$ and $95 \cdot 7 \pm 22 \cdot 8$, respectively) than the oldest age group $(26 \cdot 3 \pm 1 \cdot 6,34 \cdot 4 \pm 3 \cdot 3$ and $40 \cdot 7 \pm 3 \cdot 3$, respectively), however the uncertainty intervals are wide for the youngest age group. Overall, mortality rates decreased with time, but the risk gradient versus age has remained similar.

In both regions, the risk gradient versus age appears in both rural and urban locations (Figure 1). Similar age gradients were observed when dividing mothers by maternal education status and other variables (Table 1).

During the survey period 2014-2018 in SSA, under-5 mortality rates of children who were born at home and to mothers aged $<16$ and $16-17(215 \cdot 4 \pm 22 \cdot 2$ and $150 \cdot 9 \pm 3 \cdot 1$ per 1000 live births, respectively) were about three times and two times higher than mortality rate of those born at home and to mothers aged 23-25 (74.5 $\pm 2 \cdot 9)$. Similar trends were seen in South Asia; however the uncertainty intervals are wide for the mothers aged $<16$ in this region due to their smaller numbers (Table 1).

\section{Multivariate Analysis Adjusting for Risk Factors}

Estimates from Models 0, 1 and 2 for the period 2014-2018 are shown in Figures 2-4. Under these models, adjusted maternal-age effects are consistent with the patterns of Table 1 and Figure 1. Mortality risk for all endpoints increases with younger age, and children in both regions born to mothers aged $<16$ faced 2-4 times higher mortality risk than those born to mothers aged 23-25 years old at all stages, from stillbirth to under-5 mortality (Figure 2), even after adjustment for demographic factors (Figure 3). The odds ratio (OR) for stillbirth is particularly high with under-16 mothers, around 
medRxiv preprint doi: https://doi.org/10.1101/2021.06.10.21258227; this version posted June 12, 2021. The copyright holder for this preprint (which was not certified by peer review) is the author/funder, who has granted medRxiv a license to display the preprint in perpetuity.

It is made available under a CC-BY 4.0 International license .

4 or more in both regions and models. Adjusting for health-seeking variables reduced the age effect for neonatal and infant mortality but not for under- 5 mortality in both regions (Figure 4 and eFigure 4 ). However, for stillbirths, the risk gradient versus age was stronger, proposing that some of the healthseeking recorded in the survey could be related to the actual stillbirths, and mothers might have had an unplanned ANC visit or gave birth at a facility due to pregnancy complications. It should be emphasized that the dataset used in Figures 4 and S4 is smaller than the one used in Figures 1-3 since the healthcare variables were available only for the last birth in the three/five years preceding the survey. Further adjustment for wealth quintile did not modify the age effect significantly (Model 3, eFigure 3). For the 2009-2013 time period in SSA, similar patterns were observed (eFigures 5-9), and in South Asia with the sampler sample size, the age effect was reduced. For the 2004-2008 time period, the risk gradient versus age appeared in both regions for majority of child outcomes (eFigures 10-14).

\section{Discussion}

Among young mothers in SSA and South Asia, there was a consistent risk gradient versus maternal age at all stages of child mortality for all survey periods. Compared with other known risk factors, young maternal age appears to be among the strongest risk factors of child mortality. Our findings confirm and substantially expand the conclusions from previous studies about the association between early childbearing and adverse child health outcomes, ${ }^{2,18,19}$ and suggest that the increased risk to children of younger mothers continues to linger even in regions with dropping adolescent pregnancy rates such as South Asia. Even in adjusted analyses, after controlling for several risk factors, the associations between adolescent pregnancy and child health outcomes remained significant. The age effect for neonatal and infant mortality was reduced after the adjustment for health-seeking variables, but not for the under-5 mortality, suggesting that ensuring young mothers receive quality care can reduce some of the early childbearing effect. The overall risk of death is higher among neonates, infants, and children of mothers in the poorest wealth quantile living in rural areas with no formal education, across all age groups. The heterogenous and limited progress in reducing adolescent pregnancies amongst these vulnerable groups emphasizes the inequity as well as inadequate 
medRxiv preprint doi: https://doi.org/10.1101/2021.06.10.21258227; this version posted June 12, 2021. The copyright holder for this preprint (which was not certified by peer review) is the author/funder, who has granted medRxiv a license to display the preprint in perpetuity.

It is made available under a CC-BY 4.0 International license .

distribution of resources and health services. ${ }^{12,20}$ However, the risk trend among younger mothers was evident across all SES groups, suggesting that beyond external social factors placing children of younger mothers at a disadvantage, underlying biological or behavioral immaturity of the mother were likely also at play. ${ }^{9,21}$ Past studies have found that coinciding pregnancy with growth in young adolescents may lead to maternal-fetal competition for nutrients and consequently, to increased risk of low birth weight, neonatal mortality, and preterm delivery. ${ }^{22,23}$

A high mortality risk of children under-5 highlights the likely long-term impact of limited education and livelihood opportunities for adolescent mothers. ${ }^{24}$ This can initiate a poverty cycle in their families, in addition to psychological and mental health problems from social stigma that young mothers may deal with. ${ }^{24,25}$ To reduce neonatal and under-5 mortality rates towards Sustainable Development Goals (SDG) targets, focusing efforts on reducing births in adolescents in countries where they are prevalent, or ensuring adolescent girls and young women have access to sexual and reproductive health services to prevent poor health outcomes for themselves and their children, is necessary.

Previous studies have found strong associations between adolescent motherhood and child or early marriage, particularly in African and Asian contexts where marriage usually precedes childbearing. ${ }^{11}$ Moreover, early marriage before age 18 has been positively associated with higher fertility, poorer maternal and reproductive health, and poorer health and developmental outcomes among their children, through pathways including biological factors, social risks, and maternal behavior. ${ }^{26,27}$ Despite existing laws and human rights frameworks calling to eliminate marriage of girls before age 18,650 million girls and women alive today married before their $18^{\text {th }}$ birthday; $40 \%$ of those women live in South Asia while $18 \%$ live in SSA. ${ }^{28}$ Strengthening measures to delay age at marriage can help reduce early pregnancies.

Our work has some limitations. There is likely under-reporting of mortality at early stages of child life, especially neonatal death and stillbirth. Further, survey responses rely on recall data, ${ }^{2}$ and respondents 
medRxiv preprint doi: https://doi.org/10.1101/2021.06.10.21258227; this version posted June 12, 2021. The copyright holder for this preprint (which was not certified by peer review) is the author/funder, who has granted medRxiv a license to display the preprint in perpetuity.

It is made available under a CC-BY 4.0 International license .

may overstate their ages at births during the interview due to social pressure. In addition, besides the risk factors we accounted for in our study, other covariates related to the pregnancy-induced complications,${ }^{13}$ which are not available in the DHS datasets, could help better explain the observed patterns. The limited sample size of the group suffering the greatest disparities, under-16 mothers, constrained the number of variables we could consider in any single model, particularly in South Asia, and with respect to health-seeking variables. The limited sample size required us to group all mothers under 16 in the main analysis. In sensitivity analysis, we divided the under-16 age group into two roughly equal groups of 10-14 and 15 years old in SSA for the unadjusted Model 0 as well as Model 1 and the period 2014-2018 (eFigures 15 and 16). Results showed a strong age effect for all child health outcomes with children of 10-14 years old mothers doing even worse than the combined under-16 group. However, the small sample size did not allow us to do any further analysis. Similarly, after examining the maternal mortality DHS module we decided to not include maternal mortality in our analysis, due to the small sample size and lack of risk factors in this module, whose data are based on living-sibling interviews. All the above-mentioned limitations in retrospective analyses of crosssectional survey data restrain the ability to disentangle the underlying biological, behavioral, and environmental mechanisms, and to rule out the residual confounding factors. There is a need for longitudinal studies and follow-up data in diverse contexts to help tease apart the drivers of adverse child outcomes for young mothers.

Our study highlights the empirical differences within the under-20 age group, and provides quantitative evidence on the necessity for age-disaggregated reporting and survey data on adolescent motherhood to better understand its associations with child outcomes and how their nature, scale, and impact vary by age. Revising the future classification of maternal age, and reporting of adolescent reproductive health, will help better develop and monitor the progress of age-specific programs aimed at achieving the SDGs of reducing adolescent pregnancy. ${ }^{29}$ By building upon previous studies and policies, our work is more cognizant of empirical and health-seeking contexts, and suggests the path forward with new policies. Some age-specific programs could be related to increasing awareness on the importance of interventions, laws and enforcement, and advocacy addressing individual and 
medRxiv preprint doi: https://doi.org/10.1101/2021.06.10.21258227; this version posted June 12, 2021. The copyright holder for this preprint (which was not certified by peer review) is the author/funder, who has granted medRxiv a license to display the preprint in perpetuity.

It is made available under a CC-BY 4.0 International license .

community barriers to delaying first pregnancy, including delaying marriage through establishing and enforcing laws, ${ }^{30}$ addressing underlying social and economic drivers and norms, empowering young women to choose if, when, and whom they marry, and enabling young women to continue and attain higher levels of education. Interventions focused on expanding contraceptive access and use are key toward shifting social and gender norms at family and community levels, ${ }^{25}$ addressing early pregnancy, and subsequently improving child outcomes. ${ }^{31}$

\section{Contributors}

JLP and APO helped develop the research concept and approach. NN analyzed the data and wrote the initial draft of the manuscript. YE provided subject-matter expertise and guideline. NN, JLP, YE, and APO contributed to the interpretation of results, and writing of the manuscript. All authors have read and approved the final manuscript.

\section{Declaration of interests}

We declare no competing interests.

\section{Ethics Approval}

This study was based on secondary analysis of Demographic and Health Surveys (DHS) data. The ethical clearance was provided by the Institutional Review Board of ICF International. Therefore, this secondary analysis was exempt from ethical review approval, since it used publicly available, deidentified data.

\section{Acknowledgement}

We would like to thank Dr. Guillaume Chabot-Couture and Dr. Edward Wenger for their useful and constructive comments and insights. 
medRxiv preprint doi: https://doi.org/10.1101/2021.06.10.21258227; this version posted June 12, 2021. The copyright holder for this preprint (which was not certified by peer review) is the author/funder, who has granted medRxiv a license to display the preprint in perpetuity.

It is made available under a CC-BY 4.0 International license .

\section{Role of the funding source}

The funders had no role in the analysis, or interpretation of the data; the preparation, review, or approval of the report; or the decision to submit the manuscript for publication. All authors are employees of the Bill and Melinda Gates Foundation, however, this study does not necessarily represent the views of the Bill and Melinda Gates Foundation.

\section{Supplementary Material}

Supplementary Material.pdf

\section{References}

1. WHO. Adolescent pregnancy-WHO. https:/www.who.int/news-room/ factsheets/detail/adolescent-pregnancy. Accessed February 3, 2021.

2. Neal S, Channon AA, Chintsanya J. The impact of young maternal age at birth on neonatal mortality: Evidence from 45 low and middle income countries. PLoS One. 2018;13(5):1-16. Available from: http://dx.doi.org/10.1371/journal.pone.0195731.

3. UNICEF. Early childbearing - UNICEF data. https://data.unicef.org/ topic/childhealth/adolescent-health/. Accessed February 3, 2021.

4. Huda, MM, O’Flaherty M, Finlay JE, Al Mamun A. Time trends and sociodemographic inequalities in the prevalence of adolescent motherhood in 74 low-income and middle-income countries: a population-based study. Lancet Child Adolesc Health. 2021;51: 26-36.

5. Chen XK, Wen ShW, Fleming N, Demissie K, Rhoads GG, Walker M. Teenage pregnancy and adverse birth outcomes: A large population based retrospective cohort study. Int J Epidemiol. 2007;36(2): 368-373.

6. Finlay JE, Özaltin E, Canning D. The association of maternal age with infant mortality, child anthropometric failure, diarrhoea and anaemia for first births: Evidence from 55 low- and middleincome countries. BMJ Open. 2011;1(2). 
medRxiv preprint doi: https://doi.org/10.1101/2021.06.10.21258227; this version posted June 12, 2021. The copyright holder for this preprint (which was not certified by peer review) is the author/funder, who has granted medRxiv a license to display the preprint in perpetuity.

It is made available under a CC-BY 4.0 International license .

7. Finlay JE, Norton MK, Guevara IM. Adolescent fertility and child health: The interaction of maternal age, parity and birth intervals in determining child health outcomes. Int $J$ Child Health Nutr. 2017;6(1):16-33.

8. Fall CHD, Sachdev HS, Osmond C, Restrepo-Mendez MC, et al. Association between maternal age at childbirth and child and adult outcomes in the offspring: A prospective study in five low-income and middle-income countries (COHORTS collaboration). Lancet Glob Health. 2015;3(7):e366-e377. http://dx.doi.org/10.1016/S2214-109X(15)00038-8.

9. Althabe F, Moore JL, Gibbons L, et al. Adverse maternal and perinatal outcomes in adolescent pregnancies: The Global Network's Maternal Newborn Health Registry study. Reprod Health. 2015;12(2):1-9.

10. GBD 2017 Child and Adolescent Health Collaborators. Diseases, Injuries, and Risk Factors in Child and Adolescent Health, 1990 to 2017: Findings From the Global Burden of Diseases, Injuries, and Risk Factors 2017 Study. JAMA Pediatr. 2019;173(6):e190337. doi:10.1001/jamapediatrics.2019.0337

11. Neal S, Channon AA, Chandra-Mouli V, Madise N. Trends in adolescent first births in sub-Saharan Africa: a tale of increasing inequity? Int J Equity Health. 2020;19(151):1-11. Available from: https://doi.org/10.1186/s12939-020-01251-y

12. Patton GC, Olsson CA, Skirbekk V, et al. Adolescence and the next generation. Nature. 2018;554: 458-467. https://doi.org/10.1038/nature25759

13. Wu H, Zhao M, Liang Y, Liu F, Xi B. Maternal age at birth and neonatal mortality: Associations from 67 low-income and middle-income countries. Paediatr Perinat Epidemiology. 2020:00:1-10. doi: 10.1111/ppe.12734.

14. Grønvik T, Fossgard SI. Complications associated with adolescent childbearing in Sub-Saharan Africa: A systematic literature review and meta-analysis. PLoS One. 2018;13(9):e0204327. https://doi.org/10.1371/journal. pone.0204327

15. The DHS Program-Quality information to plan, monitor and improve population, health, and nutrition programs. http://dhsprogram.com/ 
medRxiv preprint doi: https://doi.org/10.1101/2021.06.10.21258227; this version posted June 12, 2021. The copyright holder for this preprint (which was not certified by peer review) is the author/funder, who has granted medRxiv a license to display the preprint in perpetuity.

It is made available under a CC-BY 4.0 International license .

16. Croft, Trevor N, Aileen M J Marshall, Courtney K Allen. Guide to DHS Statistics. Rockville, Maryland, USA: ICF; 2018.

17. R Core Team. A language and environment for statistical computing; 2013. R Foundation for Statistical Computing, Vienna, Austria. https://www.r-project.org/.

18. Oyeyemi AL, Aliyu SU, Sa'Ad F, Rufa'I AA, Jajere ARM, Oyeyemi AY. Association between adolescent motherhood and maternal and child health indices in Maiduguri, Nigeria: A community based cross-sectional study. BMJ Open. 2019;9(3):1-9.

19. Kozuki N, Lee AC, Silveira MF, et al. The associations of parity and maternal age with small-forgestational-age, preterm, and neonatal and infant mortality: A meta-analysis. BMC Public Health. 2013;13 Suppl 3(Suppl 3):S2. doi: 10.1186/1471-2458-13-S3-S2.

20. Decker MR, Kalamar A, Tuncalp O, Hindin MJ. Early adolescent childbearing in low- and middleincome countries: associations with income inequity, human development and gender equality. Health Policy Plan. 2017;32(2): 277-282. doi: 10.1093/heapol/czw121

21. Saloojee H, Coovadia H. Maternal age matters: For a lifetime, or longer. Lancet Glob Health. 2015;3(7):e342-e343. http://dx.doi.org/10.1016/ S2214-109X(15)00034-0.

22. Yu SH, Mason J, Crum J, Cappa C, Hotchkiss DR. Differential effects of young maternal age on child growth. Glob Health Action. 2016;9(1). DOI: 10.3402/gha.v9.31171

23. Wallace JM. Competition for nutrients in pregnant adolescents: Consequences for maternal, conceptus and offspring endocrine systems. J Endocrinol. 2019;242(1):T1-T19.

24. Yakubu I, Salisu WJ. Determinants of adolescent pregnancy in sub-Saharan Africa: a systematic review. Reprod Health. 2018;15: 1-11. DOI 10.1186/s12978-018-0460-4

25. Habitu YA, Yalew A, Bisetegn TZ. Prevalence and factors associated with teenage pregnancy, northeast Ethiopia, 2017: a cross-sectional study. $J$ Pregnancy. 2018:1-7. https://doi.org/10.1155/2018/1714527

26. Efevbera Y, Bhabha J, Farmer PE, Fink G. Girl child marriage as a risk factor for early childhood development and stunting. Soc Sci Med. 2017;185:91-101. doi: 10.1016/j.socscimed.2017.05.027. 
medRxiv preprint doi: https://doi.org/10.1101/2021.06.10.21258227; this version posted June 12, 2021. The copyright holder for this preprint (which was not certified by peer review) is the author/funder, who has granted medRxiv a license to display the preprint in perpetuity.

It is made available under a CC-BY 4.0 International license .

27. Wooden Q, Male Ch, Nayihouba A, et al. Economic impacts of child marriage: global synthesis report. 2017.

28. UNICEF. Child marriage, latest trends and future prospects. https://data.unicef.org/resources/child-marriage-latest-trends-and-future-prospects/. Accessed April 1, 2021.

29. Kassa GM, Arowojolu AO, Odukogbe AA, Yalew AW. Prevalence and determinants of adolescent pregnancy in Africa: A systematic review and Meta-analysis. Reprod Health. 2018;15(1):117. https://doi.org/10.1186/s12978-018-0640-2

30. Maswikwa B, Richter L, Kaufman J, Nandi A. Minimum marriage age laws and the prevalence of child marriage and adolescent birth: Evidence from sub-Saharan Africa. Int Perspect Sex Reprod Health. 2015;41(2): 58-68.

31. Speizer IS, Calhoun LM. Her, his, and their fertility desires and contraceptive behaviours: A focus on young couples in six countries. Glob Public Health. 2021 May 3:1-17. DOI: $10.1080 / 17441692.2021 .1922732$ 
Table 1. Mortality rates of different child health outcomes and their sampling errors in Sub-Saharan Africa and South Asia

\begin{tabular}{|c|c|c|c|c|c|c|c|c|c|}
\hline \multicolumn{10}{|c|}{ Sub-Saharan Africa } \\
\hline & \multicolumn{3}{|c|}{ 2004-2008 } & \multicolumn{3}{|c|}{ 2009-2013 } & \multicolumn{3}{|c|}{ 2014-2018 } \\
\hline & NNMR $^{\mathbf{a}}$ & $\mathbf{I M R}^{\mathbf{b}}$ & U5MR ${ }^{\mathrm{c}}$ & NNMR & IMR & U5MR & NNMR & IMR & U5MR \\
\hline \multicolumn{10}{|c|}{ Maternal age at first birth (years) } \\
\hline$<16$ & $85.1 \pm 5$ & $152.8 \pm 6.5$ & $238.5 \pm 7.5$ & $63.8 \pm 4.0$ & $117.7 \pm 5.3$ & $186.2 \pm 6.2$ & $54.5 \pm 4.5$ & $95.9 \pm 5.5$ & $156.5 \pm 6.6$ \\
\hline $16-17$ & $58.3 \pm 2.3$ & $115.8 \pm 3.1$ & $188.3 \pm 3.9$ & $49.8 \pm 1.9$ & $91.3 \pm 2.6$ & $145.2 \pm 3.3$ & $44.4 \pm 2.0$ & $72.5 \pm 2.6$ & $112.8 \pm 3.2$ \\
\hline $18-19$ & $46.9 \pm 1.8$ & $89 \pm 2.3$ & $146 \pm 2.9$ & $39.1 \pm 1.4$ & $73.8 \pm 1.9$ & $115.5 \pm 2.3$ & $34.4 \pm 1.4$ & $58 \pm 1.8$ & $88.2 \pm 2.2$ \\
\hline $20-22$ & $39.9 \pm 1.4$ & $79.3 \pm 2.1$ & $127.3 \pm 2.6$ & $35.8 \pm 1.2$ & $62.4 \pm 1.6$ & $98.6 \pm 2.0$ & $29.8 \pm 1.2$ & $50.3 \pm 1.5$ & $74.6 \pm 1.8$ \\
\hline $23-25$ & $40.2 \pm 2.1$ & $74.5 \pm 2.8$ & $123.5 \pm 3.7$ & $33.7 \pm 1.8$ & $55.7 \pm 2.2$ & $88.8 \pm 2.7$ & $28 \pm 1.6$ & $44.5 \pm 1.9$ & $64.8 \pm 2.4$ \\
\hline \multicolumn{10}{|c|}{ Urban/Rural Residency } \\
\hline$<16$ & $\begin{array}{c}53.2 \pm 2.9 \\
92.6 \pm 13.7\end{array}$ & $\begin{array}{c}115.6 \pm 6.1 \\
161.6 \pm 13.1\end{array}$ & $\begin{array}{c}182.6 \pm 10 \\
251.9 \pm 10.5\end{array}$ & $\begin{array}{c}58.3 \pm 16.2 \\
65.8 \pm 1.0\end{array}$ & $\begin{array}{c}108.1 \pm 16.2 \\
121.3 \pm 1.9\end{array}$ & $\begin{array}{c}159.1 \pm 15.5 \\
196.1 \pm 3.9\end{array}$ & $\begin{array}{c}43.2 \pm 3.1 \\
58.6 \pm 18.7\end{array}$ & $\begin{array}{c}74.1 \pm 9 \\
103.6 \pm 18.3\end{array}$ & $\begin{array}{l}115.9 \pm 10.6 \\
170.9 \pm 16.8\end{array}$ \\
\hline $16-17$ & $\begin{array}{l}50.2 \pm 2.4 \\
60.7 \pm 2.1\end{array}$ & $\begin{array}{c}97.6 \pm 2.3 \\
121.2 \pm 3.1\end{array}$ & $\begin{array}{l}160.4 \pm 2.3 \\
196.8 \pm 6.9\end{array}$ & $\begin{array}{l}30.2 \pm 3.2 \\
57.8 \pm 2.0\end{array}$ & $\begin{array}{c}63.7 \pm 3.2 \\
102.5 \pm 2.3\end{array}$ & $\begin{array}{l}100.1 \pm 3.4 \\
163.6 \pm 2.8\end{array}$ & $\begin{array}{c}39 \pm 13.2 \\
46.3 \pm 1\end{array}$ & $\begin{array}{c}62.4 \pm 13.9 \\
76.2 \pm 1.7\end{array}$ & $\begin{array}{l}90.6 \pm 13.6 \\
121.2 \pm 2.3\end{array}$ \\
\hline $18-19$ & $\begin{array}{l}39.2 \pm 2.4 \\
49.8 \pm 2.7\end{array}$ & $\begin{array}{l}75.2 \pm 2.5 \\
94.1 \pm 2.9\end{array}$ & $\begin{array}{c}119.2 \pm 2.9 \\
156 \pm 3.4\end{array}$ & $\begin{array}{l}33.5 \pm 1.8 \\
41.6 \pm 2.0\end{array}$ & $\begin{array}{l}59.9 \pm 2.0 \\
80.3 \pm 2.8\end{array}$ & $\begin{array}{c}87.8 \pm 2.7 \\
128.4 \pm 3.6\end{array}$ & $\begin{array}{l}25.9 \pm 3.2 \\
37.9 \pm 3.1\end{array}$ & $\begin{array}{l}45.2 \pm 4 \\
63.5 \pm 3\end{array}$ & $\begin{array}{c}67.5 \pm 4.1 \\
97.1 \pm 3\end{array}$ \\
\hline $20-22$ & $\begin{array}{c}30 \pm 1.8 \\
44.2 \pm 1.2\end{array}$ & $\begin{array}{l}60.6 \pm 1.8 \\
87.4 \pm 1.3\end{array}$ & $\begin{array}{c}95.2 \pm 1.9 \\
141.4 \pm 1.8\end{array}$ & $\begin{array}{l}30.7 \pm 0.3 \\
38.7 \pm 1.4\end{array}$ & $\begin{array}{l}49.5 \pm 0.7 \\
69.6 \pm 3.3\end{array}$ & $\begin{array}{c}72.9 \pm 1.3 \\
113.0 \pm 4.5\end{array}$ & $\begin{array}{l}25.5 \pm 0.9 \\
32.2 \pm 1.4\end{array}$ & $\begin{array}{l}41.3 \pm 1.5 \\
55.4 \pm 1.5\end{array}$ & $\begin{array}{c}57.9 \pm 4.5 \\
84 \pm 1.5\end{array}$ \\
\hline $23-25$ & $\begin{array}{l}30.2 \pm 0.5 \\
46.4 \pm 1.3\end{array}$ & $\begin{array}{c}56.9 \pm 2 \\
85.4 \pm 2.3\end{array}$ & $\begin{array}{c}83.3 \pm 2.1 \\
147.3 \pm 4.4\end{array}$ & $\begin{array}{l}32.4 \pm 0.3 \\
34.7 \pm 4.3\end{array}$ & $\begin{array}{l}47.9 \pm 0.9 \\
62.0 \pm 4.1\end{array}$ & $\begin{array}{c}72.4 \pm 1.2 \\
101.7 \pm 4.8\end{array}$ & $\begin{array}{l}27.6 \pm 0.4 \\
28.4 \pm 0.2\end{array}$ & $\begin{array}{c}40.5 \pm 0.5 \\
48 \pm 0.4\end{array}$ & $\begin{array}{l}55.4 \pm 0.8 \\
72.8 \pm 0.6\end{array}$ \\
\hline
\end{tabular}




\begin{tabular}{|c|c|c|c|c|c|c|c|c|c|}
\hline \multicolumn{10}{|c|}{ Sub-Saharan Africa } \\
\hline & \multicolumn{3}{|c|}{ 2004-2008 } & \multicolumn{3}{|c|}{$2009-2013$} & \multicolumn{3}{|c|}{ 2014-2018 } \\
\hline & NNMR & IMR & U5MR & NNMR & IMR & U5MR & NNMR & IMR & U5MR \\
\hline \multicolumn{10}{|c|}{ Maternal Education Status: Any Education/No Education } \\
\hline$<16$ & $\begin{array}{c}69.5 \pm 0.9 \\
95.2 \pm 15.7\end{array}$ & $\begin{array}{c}124.7 \pm 1.6 \\
170.8 \pm 15.7\end{array}$ & $\begin{array}{c}185.3 \pm 1.8 \\
271.5 \pm 13.8\end{array}$ & $\begin{array}{c}59.5 \pm 12.8 \\
67.6 \pm 1.3\end{array}$ & $\begin{array}{c}112.7 \pm 12.2 \\
122.1 \pm 3.4\end{array}$ & $\begin{array}{c}169.8 \pm 11.7 \\
199.1 \pm 5.3\end{array}$ & $\begin{array}{l}55.4 \pm 10.8 \\
53.4 \pm 16.8\end{array}$ & $\begin{array}{c}93 \pm 11.9 \\
99.2 \pm 17.3\end{array}$ & $\begin{array}{l}140.4 \pm 12.1 \\
174.5 \pm 15.8\end{array}$ \\
\hline $16-17$ & $\begin{array}{l}51.6 \pm 0.4 \\
64.9 \pm 2.8\end{array}$ & $\begin{array}{c}98.6 \pm 0.8 \\
132.6 \pm 5.1\end{array}$ & $\begin{array}{l}150.2 \pm 1.2 \\
224.7 \pm 9.4\end{array}$ & $\begin{array}{c}42.1 \pm 0.4 \\
60.3 \pm 3\end{array}$ & $\begin{array}{c}77.4 \pm 0.8 \\
110 \pm 3.3\end{array}$ & $\begin{array}{l}121.6 \pm 1.3 \\
174.7 \pm 3.6\end{array}$ & $\begin{array}{l}40.8 \pm 8.7 \\
50.6 \pm 0.7\end{array}$ & $\begin{array}{l}67.3 \pm 9.1 \\
81.4 \pm 1.1\end{array}$ & $\begin{array}{c}97.7 \pm 8.8 \\
136.3 \pm 1.7\end{array}$ \\
\hline $18-19$ & $\begin{array}{l}37.7 \pm 2.2 \\
61.6 \pm 4.5\end{array}$ & $\begin{array}{l}74.3 \pm 2.1 \\
112.1 \pm 4\end{array}$ & $\begin{array}{c}117.8 \pm 2.2 \\
189 \pm 4\end{array}$ & $\begin{array}{c}35 \pm 0.3 \\
46.4 \pm 3.8\end{array}$ & $\begin{array}{l}65.9 \pm 2.3 \\
87.8 \pm 5\end{array}$ & $\begin{array}{c}98.5 \pm 3.6 \\
143.3 \pm 5.4\end{array}$ & $\begin{array}{c}31.5 \pm 2 \\
41.1 \pm 6.7\end{array}$ & $\begin{array}{c}52.3 \pm 2 \\
71.2 \pm 6.4\end{array}$ & $\begin{array}{c}76.4 \pm 2.3 \\
113.4 \pm 6.4\end{array}$ \\
\hline $20-22$ & $\begin{array}{l}31.8 \pm 0.2 \\
56.4 \pm 2.4\end{array}$ & $\begin{array}{c}64.3 \pm 0.4 \\
109.2 \pm 2.4\end{array}$ & $\begin{array}{l}100.8 \pm 0.6 \\
178.7 \pm 3.6\end{array}$ & $\begin{array}{l}32.5 \pm 0.3 \\
42.2 \pm 2.6\end{array}$ & $\begin{array}{l}56.2 \pm 0.5 \\
74.4 \pm 5.8\end{array}$ & $\begin{array}{c}84.3 \pm 1.9 \\
124.2 \pm 7.6\end{array}$ & $\begin{array}{c}27.8 \pm 0.7 \\
35.1 \pm 3\end{array}$ & $\begin{array}{l}45.1 \pm 1.1 \\
64.2 \pm 2.8\end{array}$ & $\begin{array}{l}65.1 \pm 1.6 \\
97.9 \pm 2.6\end{array}$ \\
\hline $23-25$ & $\begin{array}{c}35 \pm 0.4 \\
52.3 \pm 2.3 \\
\end{array}$ & $\begin{array}{l}65.1 \pm 0.7 \\
96.3 \pm 4.2 \\
\end{array}$ & $\begin{array}{l}102.1 \pm 0.9 \\
169.9 \pm 7.5\end{array}$ & $\begin{array}{l}32.1 \pm 0.2 \\
37.1 \pm 6.7 \\
\end{array}$ & $\begin{array}{l}51.1 \pm 0.4 \\
65.2 \pm 6.5 \\
\end{array}$ & $\begin{array}{c}78 \pm 0.5 \\
109.6 \pm 7.6\end{array}$ & $\begin{array}{l}28.1 \pm 0.3 \\
27.9 \pm 0.1\end{array}$ & $\begin{array}{c}43 \pm 0.5 \\
48.9 \pm 0.1\end{array}$ & $\begin{array}{l}58.7 \pm 0.7 \\
81.1 \pm 0.2 \\
\end{array}$ \\
\hline \multicolumn{10}{|c|}{ Antenatal Care Visit (ANC): Any Visit/No Visit } \\
\hline$<16$ & $\begin{array}{l}33.5 \pm 1.6 \\
38.5 \pm 3.6\end{array}$ & $\begin{array}{l}79.9 \pm 4 \\
53.2 \pm 5\end{array}$ & $\begin{array}{c}187.4 \pm 15 \\
141.3 \pm 16.2\end{array}$ & $\begin{array}{l}26.7 \pm 18.6 \\
81.9 \pm 16.9\end{array}$ & $\begin{array}{c}60.7 \pm 22.3 \\
122.1 \pm 20.7\end{array}$ & $\begin{array}{c}109.3 \pm 30.8 \\
209.1 \pm 47\end{array}$ & $\begin{array}{l}27.9 \pm 3.6 \\
26.1 \pm 1.8\end{array}$ & $\begin{array}{c}43.9 \pm 5.7 \\
85.2 \pm 17.6\end{array}$ & - \\
\hline $16-17$ & $\begin{array}{c}27 \pm 1 \\
57.4 \pm 2\end{array}$ & $\begin{array}{c}60.2 \pm 2.2 \\
93.6 \pm 10.6\end{array}$ & $\begin{array}{c}94.2 \pm 11.1 \\
173.1 \pm 11.8\end{array}$ & $\begin{array}{c}24.8 \pm 0.5 \\
28.8 \pm 14.7\end{array}$ & $\begin{array}{c}51.6 \pm 1.1 \\
64.3 \pm 14.4\end{array}$ & $\begin{array}{c}93 \pm 2 \\
95.8 \pm 14.2\end{array}$ & $\begin{array}{c}24.3 \pm 0.7 \\
41 \pm 1.5\end{array}$ & $\begin{array}{l}39.8 \pm 1.1 \\
79.2 \pm 2.8\end{array}$ & $\begin{array}{c}64.8 \pm 1.3 \\
41 \pm 5.2\end{array}$ \\
\hline $18-19$ & $\begin{array}{c}25.7 \pm 0.7 \\
0.8 \pm 1.7\end{array}$ & $\begin{array}{l}48.5 \pm 1.4 \\
77.3 \pm 3.3\end{array}$ & $\begin{array}{c}80.8 \pm 2.4 \\
132.6 \pm 3.6\end{array}$ & $\begin{array}{l}23.7 \pm 0.4 \\
36.6 \pm 1.3\end{array}$ & $\begin{array}{l}47.8 \pm 3.8 \\
60.3 \pm 7.6\end{array}$ & $\begin{aligned} 87.9 & \pm 3.7 \\
176.2 & \pm 11.1\end{aligned}$ & $\begin{array}{l}19.4 \pm 3.7 \\
38.3 \pm 1.3\end{array}$ & $\begin{array}{l}32.1 \pm 3.5 \\
62.8 \pm 2.3\end{array}$ & $\begin{array}{c}52.4 \pm 3.3 \\
103.9 \pm 3.4\end{array}$ \\
\hline $20-22$ & $\begin{array}{c}22.8 \pm 0.4 \\
53 \pm 2\end{array}$ & $\begin{array}{r}48.5 \pm 0.7 \\
101.7 \pm 4\end{array}$ & $\begin{array}{c}77.3 \pm 1.1 \\
206.9 \pm 18.9\end{array}$ & $\begin{array}{l}22.6 \pm 0.4 \\
6.2 \pm 15.3\end{array}$ & $\begin{array}{c}41.1 \pm 0.6 \\
74.5 \pm 18.2\end{array}$ & $\begin{aligned} 59.8 & \pm 0.8 \\
150.1 & \pm 19.7\end{aligned}$ & $\begin{array}{l}15.9 \pm 0.2 \\
42.8 \pm 1.6\end{array}$ & $\begin{array}{l}27.4 \pm 0.3 \\
82.1 \pm 2.9\end{array}$ & $\begin{array}{c}38.2 \pm 0.4 \\
125.4 \pm 4.2\end{array}$ \\
\hline $23-25$ & $\begin{array}{l}26.1 \pm 0.7 \\
24.7 \pm 1.2\end{array}$ & $\begin{array}{c}52.3 \pm 1.4 \\
43.1 \pm 15.4\end{array}$ & $\begin{array}{c}82.7 \pm 1.9 \\
132.2 \pm 248.3\end{array}$ & $\begin{array}{l}21.3 \pm 0.3 \\
20.6 \pm 1.2\end{array}$ & $\begin{array}{l}36.8 \pm 0.4 \\
44.9 \pm 2.7\end{array}$ & $\begin{array}{l}65.4 \pm 0.5 \\
63.1 \pm 3.8\end{array}$ & $\begin{array}{l}16.5 \pm 0.9 \\
15.2 \pm 1.2\end{array}$ & $\begin{array}{c}24.9 \pm 1 \\
52.3 \pm 4.5\end{array}$ & $\begin{array}{l}34.1 \pm 1.4 \\
96.1 \pm 9.9\end{array}$ \\
\hline
\end{tabular}




\begin{tabular}{|c|c|c|c|c|c|c|c|c|c|c|c|}
\hline \multicolumn{12}{|c|}{ Sub-Saharan Africa } \\
\hline & \multicolumn{5}{|c|}{ 2004-2008 } & \multicolumn{3}{|c|}{ 2009-2013 } & \multicolumn{3}{|c|}{ 2014-2018 } \\
\hline & NNMR & \multicolumn{2}{|c|}{ IMR } & \multicolumn{2}{|c|}{ U5MR } & NNMR & IMR & U5MR & NNMR & IMR & U5MR \\
\hline \multicolumn{12}{|c|}{ Place of Delivery: At Home/Health Facility } \\
\hline$<16$ & $\begin{array}{c}88 \pm 8.8 \\
59.8 \pm 19\end{array}$ & \multicolumn{2}{|c|}{$\begin{array}{c}161 \pm 9.5 \\
94.2 \pm 21.5\end{array}$} & \multicolumn{2}{|c|}{$\begin{array}{l}253.1 \pm 11.6 \\
188.8 \pm 31.2\end{array}$} & $\begin{array}{c}65.5 \pm 2.9 \\
38.6 \pm 31.1\end{array}$ & $\begin{array}{l}116.9 \pm 5.3 \\
73.6 \pm 31.3\end{array}$ & $\begin{array}{l}214.3 \pm 11.9 \\
138.2 \pm 29.2\end{array}$ & $\begin{array}{l}53 \pm 26.4 \\
41.1 \pm 2.1\end{array}$ & $\begin{array}{c}105.7 \pm 25.1 \\
78.6 \pm 11\end{array}$ & $\begin{array}{c}215.4 \pm 22.2 \\
140 \pm 11.9\end{array}$ \\
\hline $16-17$ & $\begin{array}{c}53.8 \pm 1.2 \\
41.7 \pm 3\end{array}$ & \multicolumn{2}{|c|}{$\begin{array}{c}108.5 \pm 2.5 \\
88.6 \pm 3.9\end{array}$} & \multicolumn{2}{|c|}{$\begin{array}{c}187.3 \pm 5.4 \\
138.1 \pm 9\end{array}$} & $\begin{array}{l}56.3 \pm 1.5 \\
32.9 \pm 0.6\end{array}$ & $\begin{array}{l}90.3 \pm 2.5 \\
68.1 \pm 1.3\end{array}$ & $\begin{array}{l}156.1 \pm 5.5 \\
114.7 \pm 2.6\end{array}$ & $\begin{array}{c}51.2 \pm 1.1 \\
34.7 \pm 1\end{array}$ & $\begin{array}{l}80.8 \pm 1.7 \\
60.1 \pm 1.6\end{array}$ & $\begin{array}{c}150.9 \pm 3.1 \\
91.6 \pm 1.8\end{array}$ \\
\hline $18-19$ & $\begin{array}{c}46.5 \pm 5.2 \\
35 \pm 1.1 \\
\end{array}$ & \multicolumn{2}{|c|}{$\begin{array}{l}92.5 \pm 5 \\
65.1 \pm 2\end{array}$} & \multicolumn{2}{|c|}{$\begin{array}{l}148.6 \pm 7.2 \\
100.9 \pm 2.9\end{array}$} & $\begin{array}{l}41.5 \pm 8.4 \\
32.2 \pm 0.6\end{array}$ & $\begin{array}{l}78.9 \pm 7.7 \\
59.8 \pm 1.1\end{array}$ & $\begin{array}{r}132.1 \pm 7 \\
94.4 \pm 1.8 \\
\end{array}$ & $\begin{array}{l}41.2 \pm 7.5 \\
30.9 \pm 0.7\end{array}$ & $\begin{array}{c}72.5 \pm 6.7 \\
46.9 \pm 1\end{array}$ & $\begin{array}{c}117 \pm 6.1 \\
68.2 \pm 1.7\end{array}$ \\
\hline $20-22$ & $\begin{array}{l}43.5 \pm 0.7 \\
33.3 \pm 0.6\end{array}$ & \multicolumn{2}{|c|}{$\begin{array}{l}90.3 \pm 1.4 \\
65.2 \pm 1.1 \\
\end{array}$} & & $\begin{array}{l}1.8 \pm 2.8 \\
0.7 \pm 1.7\end{array}$ & $\begin{array}{l}44.2 \pm 1.3 \\
31.1 \pm 0.6\end{array}$ & $\begin{array}{l}70.8 \pm 2.2 \\
53.2 \pm 1.1\end{array}$ & $\begin{array}{c}110.4 \pm 4.1 \\
79.6 \pm 1.8\end{array}$ & $\begin{array}{l}38.2 \pm 6.7 \\
27.6 \pm 0.3\end{array}$ & $\begin{array}{l}70.6 \pm 6.5 \\
43.4 \pm 0.4\end{array}$ & $\begin{array}{c}104.9 \pm 6.5 \\
57.9 \pm 0.4\end{array}$ \\
\hline $23-25$ & $\begin{array}{l}45.9 \pm 4.4 \\
31.7 \pm 0.6\end{array}$ & & $\begin{array}{l}6 \pm 7.1 \\
2 \pm 1.2\end{array}$ & & $\begin{array}{l}0.6 \pm 6.9 \\
.2 \pm 1.7\end{array}$ & $\begin{array}{l}30.3 \pm 0.9 \\
30.7 \pm 0.3\end{array}$ & $\begin{array}{l}60.4 \pm 1.7 \\
47.9 \pm 0.4\end{array}$ & $\begin{array}{c}96.7 \pm 21.3 \\
75.2 \pm 0.4\end{array}$ & $\begin{array}{l}25.4 \pm 0.8 \\
29.5 \pm 0.6\end{array}$ & $\begin{array}{l}48.3 \pm 1.6 \\
41.3 \pm 0.8\end{array}$ & $\begin{array}{l}74.5 \pm 2.9 \\
53.6 \pm 1.1\end{array}$ \\
\hline & & & & & & & outh Asia & & & & \\
\hline & & & 2004-2 & & & & $2009-201$ & & & 2014-2018 & \\
\hline & NNI & & IMI & & U5MR & NNM & IMR & U5MR & NNMR & IMR & U5MR \\
\hline Maternal & age at first $b$ & 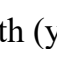 & & & & & & & & & \\
\hline$<16$ & $82.9 \pm$ & & $112.6 \pm$ & & $145 \pm 2$ & $55.4 \pm$ & $81.7 \pm 3.1$ & $98.9 \pm 6.4$ & $59.7 \pm 15$ & $84.4 \pm 20.8$ & $95.7 \pm 22.8$ \\
\hline $16-17$ & $65.6 \pm$ & & $94.8=$ & & $112.1 \pm$ & $50.8 \pm$ & $75 \pm 2.8$ & $86.9 \pm 2.9$ & $46.4 \pm 3.7$ & $64.4 \pm 5.1$ & $74 \pm 5.7$ \\
\hline 18-19 & $53.2 \pm$ & & $74.3 \pm$ & & $86.5 \pm 1$ & $45.7 \pm$ & $61.6 \pm 1.3$ & $71 \pm 2.3$ & $38.7 \pm 7.2$ & $51.4 \pm 7.3$ & $58.7 \pm 8.5$ \\
\hline $20-22$ & $39.6 \pm$ & & $56.4=$ & & $66.9 \pm$ & $32.5 \pm$ & $45.7 \pm 1.5$ & $53.6 \pm 1.5$ & $31.3 \pm 4.6$ & $41.9 \pm 4.6$ & $48.3 \pm 4.6$ \\
\hline $23-25$ & $35.5 \pm$ & & $49.6 \pm$ & & $57.5 \pm 0$ & $25.3 \pm$ & $36.4 \pm 0.3$ & $45.1 \pm 0.3$ & $26.3 \pm 1.6$ & $34.4 \pm 3.3$ & $40.7 \pm 3.3$ \\
\hline
\end{tabular}




\begin{tabular}{|c|c|c|c|c|c|c|c|c|c|}
\hline \multicolumn{10}{|c|}{ South Asia } \\
\hline & \multicolumn{3}{|c|}{ 2004-2008 } & \multicolumn{3}{|c|}{ 2009-2013 } & \multicolumn{3}{|c|}{ 2014-2018 } \\
\hline & NNMR & IMR & U5MR & NNMR & IMR & U5MR & NNMR & IMR & U5MR \\
\hline \multicolumn{10}{|c|}{ Urban/Rural Residency } \\
\hline$<16$ & $\begin{array}{l}80.2 \pm 4.2 \\
83.4 \pm 1.6\end{array}$ & $\begin{array}{l}107.3 \pm 5.6 \\
113.6 \pm 2.1\end{array}$ & $\begin{array}{l}132.1 \pm 6.5 \\
147.6 \pm 2.5\end{array}$ & $\begin{array}{l}48.8 \pm 6.2 \\
57.3 \pm 2.8\end{array}$ & $\begin{array}{c}63.5 \pm 12 \\
87.1 \pm 4.2\end{array}$ & $\begin{array}{l}86.4 \pm 11.8 \\
102.6 \pm 7.5\end{array}$ & $\begin{array}{l}56.4 \pm 33.5 \\
60.6 \pm 52.8\end{array}$ & $\begin{array}{c}71.8 \pm 42.2 \\
88 \pm 51.4\end{array}$ & $\begin{array}{c}77.1 \pm 44.1 \\
101.2 \pm 50.5\end{array}$ \\
\hline $16-17$ & $\begin{array}{c}51.1 \pm 1.7 \\
69 \pm 2.2\end{array}$ & $\begin{array}{c}71.5 \pm 2.4 \\
100.3 \pm 4.9\end{array}$ & $\begin{array}{c}87.1 \pm 3.2 \\
118.1 \pm 4.7\end{array}$ & $\begin{array}{l}34.4 \pm 3.1 \\
55.7 \pm 3.7\end{array}$ & $\begin{array}{l}53.8 \pm 4.8 \\
81.2 \pm 4.3\end{array}$ & $\begin{array}{l}60.5 \pm 4.8 \\
94.4 \pm 4.4\end{array}$ & $\begin{array}{l}27.3 \pm 4.5 \\
52.8 \pm 6.1\end{array}$ & $\begin{array}{l}44.4 \pm 7.3 \\
71.1 \pm 6.7\end{array}$ & $\begin{array}{c}54.5 \pm 8.6 \\
80.5 \pm 10.1\end{array}$ \\
\hline $18-19$ & $\begin{array}{l}36.5 \pm 0.4 \\
58.2 \pm 0.8\end{array}$ & $\begin{array}{l}53.3 \pm 0.5 \\
80.7 \pm 1.2\end{array}$ & $\begin{array}{l}61 \pm 0.6 \\
4.4 \pm 1.4\end{array}$ & $\begin{array}{c}31 \pm 1.6 \\
50.7 \pm 1.6\end{array}$ & $\begin{array}{c}48 \pm 2.1 \\
66.1 \pm 1.8\end{array}$ & $\begin{array}{l}52.6 \pm 3.4 \\
77.1 \pm 2.6\end{array}$ & $\begin{array}{c}30.4 \pm 15.2 \\
41.5 \pm 1.9\end{array}$ & $\begin{array}{c}40.5 \pm 15.3 \\
55.1 \pm 2.5\end{array}$ & $\begin{array}{c}45.8 \pm 17.8 \\
63.2 \pm 2.8\end{array}$ \\
\hline $20-22$ & $\begin{array}{c}28 \pm 0.2 \\
44.8 \pm 1.2 \\
\end{array}$ & $\begin{array}{l}39.4 \pm 0.3 \\
64.1 \pm 1.1 \\
\end{array}$ & $\begin{array}{l}45 \pm 0.4 \\
76.8 \pm 1 \\
\end{array}$ & $\begin{array}{l}21.3 \pm 0.7 \\
37.7 \pm 1.7 \\
\end{array}$ & $\begin{array}{l}30.1 \pm 0.7 \\
52.9 \pm 1.7\end{array}$ & $\begin{array}{c}35.1 \pm 1 \\
62.4 \pm 1.7\end{array}$ & $\begin{array}{l}23.1 \pm 8.8 \\
34.6 \pm 0.9\end{array}$ & $\begin{array}{l}31.2 \pm 8.7 \\
46.3 \pm 1.4\end{array}$ & $\begin{array}{l}35.1 \pm 8.7 \\
53.6 \pm 1.5\end{array}$ \\
\hline $23-25$ & $\begin{array}{l}27.1 \pm 0.2 \\
41.4 \pm 0.3\end{array}$ & $\begin{array}{l}37.2 \pm 0.2 \\
58.2 \pm 0.5\end{array}$ & $\begin{array}{l}43.5 \pm 0.3 \\
67.3 \pm 0.6\end{array}$ & $\begin{array}{c}19.2 \pm 0.1 \\
9.4 \pm 0.2\end{array}$ & $\begin{array}{l}28.7 \pm 0.5 \\
41.5 \pm 0.3\end{array}$ & $\begin{array}{l}35.6 \pm 0.5 \\
51.5 \pm 0.3\end{array}$ & $\begin{array}{l}16.6 \pm 2.5 \\
31.9 \pm 0.4\end{array}$ & $\begin{array}{c}21.9 \pm 5 \\
41.6 \pm 0.6\end{array}$ & $\begin{array}{c}26.8 \pm 5 \\
48.8 \pm 0.7\end{array}$ \\
\hline \multicolumn{10}{|c|}{ Maternal Education Status: Any Education/No Education } \\
\hline$<16$ & $\begin{array}{c}67.4 \pm 1.9 \\
100.1 \pm 0\end{array}$ & $\begin{array}{c}95 \pm 2.7 \\
132 \pm 0\end{array}$ & $\begin{array}{c}120 \pm 3.2 \\
170.9 \pm 0.4\end{array}$ & $\begin{array}{c}42.9 \pm 3.2 \\
100.2 \pm 4.6\end{array}$ & $\begin{array}{c}62.7 \pm 3.4 \\
149.4 \pm 6.7\end{array}$ & $\begin{array}{c}82.6 \pm 7.6 \\
159.5 \pm 6.9\end{array}$ & $\begin{array}{c}67.2 \pm 17.9 \\
45.1 \pm 8.3\end{array}$ & $\begin{array}{l}85.7 \pm 22.5 \\
81.5 \pm 14.4\end{array}$ & $\begin{array}{c}96 \pm 24.3 \\
94.6 \pm 16.9\end{array}$ \\
\hline $16-17$ & $\begin{array}{l}52.7 \pm 3.9 \\
83.1 \pm 0.8 \\
\end{array}$ & $\begin{array}{c}76.8 \pm 3.7 \\
118.8 \pm 5.2 \\
\end{array}$ & $\begin{array}{c}88.3 \pm 3.6 \\
142.5 \pm 5\end{array}$ & $\begin{array}{l}40.3 \pm 0.9 \\
94.5 \pm 1.6 \\
\end{array}$ & $\begin{array}{c}61 \pm 3.1 \\
132.8 \pm 2.2 \\
\end{array}$ & $\begin{array}{c}68 \pm 3.1 \\
160.5 \pm 2.6 \\
\end{array}$ & $\begin{array}{l}42.1 \pm 3.2 \\
56.8 \pm 7.1 \\
\end{array}$ & $\begin{array}{l}57.4 \pm 4.4 \\
80.8 \pm 9.9 \\
\end{array}$ & $\begin{array}{c}65 \pm 4.8 \\
94.3 \pm 11.1 \\
\end{array}$ \\
\hline $18-19$ & $\begin{array}{l}44.2 \pm 0.7 \\
68.9 \pm 0.5\end{array}$ & $\begin{array}{l}61.6 \pm 1.4 \\
96.6 \pm 0.7\end{array}$ & $\begin{array}{c}70.7 \pm 1.4 \\
113.2 \pm 0.8\end{array}$ & $\begin{array}{l}39.8 \pm 1.1 \\
72.6 \pm 0.8\end{array}$ & $\begin{array}{c}52.6 \pm 1.3 \\
102.5 \pm 1.1\end{array}$ & $\begin{array}{c}61.5 \pm 2.6 \\
113.6 \pm 1.2\end{array}$ & $\begin{array}{c}35.4 \pm 1.3 \\
47.7 \pm 20.4\end{array}$ & $\begin{array}{c}45.7 \pm 1.6 \\
66.8 \pm 20.5\end{array}$ & $\begin{array}{c}51.6 \pm 6.7 \\
77.4 \pm 20.4\end{array}$ \\
\hline $20-22$ & $\begin{array}{l}32.4 \pm 1.5 \\
59.1 \pm 0.2\end{array}$ & $\begin{array}{l}46.3 \pm 1.4 \\
83.8 \pm 0.3\end{array}$ & $\begin{array}{c}53.5 \pm 1 \\
102.1 \pm 2.9\end{array}$ & $\begin{array}{l}28.2 \pm 1.7 \\
57.5 \pm 0.3\end{array}$ & $\begin{array}{l}40.3 \pm 1.7 \\
76.7 \pm 0.4\end{array}$ & $\begin{array}{l}47.3 \pm 1.7 \\
89.5 \pm 0.5\end{array}$ & $\begin{array}{c}28.7 \pm 0.9 \\
39.9 \pm 16\end{array}$ & $\begin{array}{c}37.2 \pm 1.2 \\
56.9 \pm 15.8\end{array}$ & $\begin{array}{c}42 \pm 1.3 \\
67.4 \pm 15.7\end{array}$ \\
\hline $23-25$ & $\begin{array}{c}29 \pm 0.2 \\
63.8 \pm 0.8\end{array}$ & $\begin{array}{c}39.3 \pm 0.3 \\
93.8 \pm 1\end{array}$ & $\begin{array}{l}45.7 \pm 0.4 \\
107.2 \pm 1\end{array}$ & $\begin{array}{c}22.4 \pm 0.1 \\
46 \pm 0.6\end{array}$ & $\begin{array}{c}31.8 \pm 0.4 \\
68.9 \pm 1\end{array}$ & $\begin{array}{l}39.3 \pm 0.4 \\
85.4 \pm 1.2\end{array}$ & $\begin{array}{l}22.8 \pm 1.9 \\
40.8 \pm 2.3\end{array}$ & $\begin{array}{l}28.7 \pm 1.9 \\
57.1 \pm 6.4\end{array}$ & $\begin{array}{l}33.8 \pm 1.9 \\
67.5 \pm 6.6\end{array}$ \\
\hline
\end{tabular}




\begin{tabular}{|c|c|c|c|c|c|c|c|c|c|}
\hline \multicolumn{10}{|c|}{ South Asia } \\
\hline & \multicolumn{3}{|c|}{ 2004-2008 } & \multicolumn{3}{|c|}{ 2009-2013 } & \multicolumn{3}{|c|}{ 2014-2018 } \\
\hline & NNMR & IMR & U5MR & NNMR & IMR & U5MR & NNMR & IMR & U5MR \\
\hline \multicolumn{10}{|c|}{ Antenatal Care Visit (ANC): Any Visit/No Visit } \\
\hline$<16$ & $\begin{array}{l}23.4 \pm 0.8 \\
62.4 \pm 5.6\end{array}$ & $\begin{array}{c}56.3 \pm 2 \\
63.8 \pm 5.7\end{array}$ & $\begin{array}{l}67.1 \pm 2.4 \\
65.8 \pm 5.9\end{array}$ & - & - & - & $\begin{array}{c}29.2 \pm 2 \\
40.3 \pm 30.9\end{array}$ & $\begin{array}{c}29.2 \pm 2 \\
40.3 \pm 30.9\end{array}$ & $\begin{array}{c}55.7 \pm 7.8 \\
40.3 \pm 31\end{array}$ \\
\hline $16-17$ & $\begin{array}{l}26.4 \pm 0.5 \\
29.1 \pm 0.7\end{array}$ & $\begin{array}{c}38.9 \pm 0.7 \\
65.2 \pm 11.9\end{array}$ & $\begin{array}{c}56 \pm 1.3 \\
69.8 \pm 11.9\end{array}$ & $\begin{array}{l}19.3 \pm 2.1 \\
27.1 \pm 1.4\end{array}$ & $\begin{array}{c}23.7 \pm 2.2 \\
32 \pm 5.1\end{array}$ & $\begin{array}{c}27.1 \pm 7 \\
39.2 \pm 5.3\end{array}$ & $\begin{array}{c}19 \pm 2 \\
39.8 \pm 3.2\end{array}$ & $\begin{array}{c}25.9 \pm 2.8 \\
67 \pm 5.6\end{array}$ & $\begin{array}{c}28.4 \pm 3.2 \\
83 \pm 7.2\end{array}$ \\
\hline $18-19$ & $\begin{array}{l}26.8 \pm 0.4 \\
25.6 \pm 0.4\end{array}$ & $\begin{array}{l}35.5 \pm 0.5 \\
31.6 \pm 7.9\end{array}$ & $\begin{array}{l}40.3 \pm 0.6 \\
34.7 \pm 7.8\end{array}$ & $\begin{array}{l}19.9 \pm 0.4 \\
20.7 \pm 0.8\end{array}$ & $\begin{array}{l}24.1 \pm 0.4 \\
39.6 \pm 1.5\end{array}$ & $\begin{array}{c}27 \pm 0.5 \\
47.8 \pm 1.8\end{array}$ & $\begin{array}{l}17.8 \pm 1.2 \\
38.4 \pm 2.7\end{array}$ & $\begin{array}{c}25 \pm 1.7 \\
59.4 \pm 4.1\end{array}$ & $\begin{array}{l}27.3 \pm 1.9 \\
64.8 \pm 4.7\end{array}$ \\
\hline $20-22$ & $\begin{array}{l}23.3 \pm 0.2 \\
38.2 \pm 0.9\end{array}$ & $\begin{array}{l}31.4 \pm 0.2 \\
52.4 \pm 1.3\end{array}$ & $\begin{array}{l}36.3 \pm 0.2 \\
75.1 \pm 2.1\end{array}$ & $\begin{array}{l}12.9 \pm 3.6 \\
24.1 \pm 6.5\end{array}$ & $\begin{array}{c}16 \pm 3.6 \\
37.9 \pm 6.5\end{array}$ & $\begin{array}{l}17.5 \pm 3.6 \\
39.3 \pm 8.3\end{array}$ & $\begin{array}{c}16.6 \pm 0.7 \\
34.6 \pm 6\end{array}$ & $\begin{array}{l}22.9 \pm 0.9 \\
46.6 \pm 8.1\end{array}$ & $\begin{array}{c}25.8 \pm 1 \\
54.7 \pm 8.4\end{array}$ \\
\hline $23-25$ & $\begin{array}{l}16.8 \pm 0.2 \\
56.6 \pm 3.2\end{array}$ & $\begin{array}{l}22.7 \pm 0.2 \\
81.8 \pm 4.5\end{array}$ & $\begin{array}{c}23.2 \pm 0.2 \\
89 \pm 5.1\end{array}$ & $\begin{array}{l}11.9 \pm 0.1 \\
39.2 \pm 4.3\end{array}$ & $\begin{array}{c}18.5 \pm 0.7 \\
44.9 \pm 5\end{array}$ & $\begin{array}{c}24.9 \pm 0.7 \\
44.9 \pm 5\end{array}$ & $\begin{array}{c}15.7 \pm 3.4 \\
36 \pm 2\end{array}$ & $\begin{array}{c}20.4 \pm 3.4 \\
52 \pm 2.9\end{array}$ & $\begin{array}{l}24 \pm 3.5 \\
70.2 \pm 3\end{array}$ \\
\hline \multicolumn{10}{|c|}{ Place of Delivery: At Home/Health Facility } \\
\hline$<16$ & $\begin{array}{l}57.3 \pm 2.2 \\
74.1 \pm 6.1\end{array}$ & $\begin{array}{c}87.3 \pm 3.5 \\
109.3 \pm 8.7\end{array}$ & $\begin{array}{l}120.7 \pm 5.1 \\
109.3 \pm 8.7\end{array}$ & $\begin{array}{c}28.1 \pm 1.8 \\
40.7 \pm 40.4\end{array}$ & $\begin{array}{c}34.9 \pm 2.3 \\
65.7 \pm 39.7\end{array}$ & $\begin{array}{l}50.3 \pm 35.8 \\
65.7 \pm 39.7\end{array}$ & $\begin{array}{c}53.7 \pm 14.9 \\
55.7 \pm 2.6\end{array}$ & $\begin{array}{c}79.4 \pm 24.1 \\
75.3 \pm 3.6\end{array}$ & $\begin{array}{c}112.5 \pm 24.2 \\
141.1 \pm 9.2\end{array}$ \\
\hline $16-17$ & $\begin{array}{c}61.2 \pm 3.3 \\
62 \pm 1.8\end{array}$ & $\begin{array}{l}91.9 \pm 5.4 \\
83.6 \pm 2.4\end{array}$ & $\begin{array}{c}103.9 \pm 5.3 \\
94.3 \pm 2.6\end{array}$ & $\begin{array}{c}36.3 \pm 0.8 \\
38 \pm 0.8\end{array}$ & $\begin{array}{c}56.2 \pm 1.1 \\
38 \pm 0.8\end{array}$ & $\begin{array}{l}64.3 \pm 1.1 \\
47.7 \pm 1.2\end{array}$ & $\begin{array}{c}53.9 \pm 4 \\
41.7 \pm 3.5\end{array}$ & $\begin{array}{l}80.4 \pm 5.9 \\
56.9 \pm 4.9\end{array}$ & $\begin{array}{l}88.2 \pm 6.1 \\
67.4 \pm 6.5\end{array}$ \\
\hline $18-19$ & $\begin{array}{l}50.4 \pm 1.2 \\
47.2 \pm 0.6\end{array}$ & $\begin{array}{c}69.9 \pm 3.6 \\
60 \pm 0.7\end{array}$ & $\begin{array}{c}89 \pm 3.5 \\
66.8 \pm 0.8\end{array}$ & $\begin{array}{l}48.5 \pm 0.9 \\
32.6 \pm 0.9\end{array}$ & $\begin{array}{l}58.5 \pm 1.1 \\
40.9 \pm 1.2\end{array}$ & $\begin{array}{l}68.7 \pm 6.3 \\
46.2 \pm 1.4\end{array}$ & $\begin{array}{l}43.4 \pm 2 \\
34.7 \pm 3\end{array}$ & $\begin{array}{l}64.4 \pm 3.2 \\
46.5 \pm 4.1\end{array}$ & $\begin{array}{c}70.1 \pm 3.3 \\
52 \pm 4.7\end{array}$ \\
\hline $20-22$ & $\begin{array}{c}43.4 \pm 2.6 \\
30 \pm 0.3\end{array}$ & $\begin{array}{c}61 \pm 2.5 \\
38.3 \pm 0.4\end{array}$ & $\begin{array}{l}78.1 \pm 3.8 \\
43.1 \pm 0.4\end{array}$ & $\begin{array}{c}30.4 \pm 0.5 \\
26 \pm 0.2\end{array}$ & $\begin{array}{l}41.5 \pm 0.7 \\
32.3 \pm 0.2\end{array}$ & $\begin{array}{c}49.7 \pm 0.9 \\
38 \pm 0.2\end{array}$ & $\begin{array}{c}46 \pm 4.7 \\
27.2 \pm 1.9\end{array}$ & $\begin{array}{l}60.9 \pm 6.4 \\
37.1 \pm 2.6\end{array}$ & $\begin{array}{c}79.1 \pm 10.1 \\
43.7 \pm 3\end{array}$ \\
\hline $23-25$ & $\begin{array}{l}46.9 \pm 0.6 \\
29.3 \pm 0.4\end{array}$ & $\begin{array}{l}68.2 \pm 0.8 \\
36.7 \pm 0.5\end{array}$ & $\begin{array}{l}76.6 \pm 0.9 \\
41.8 \pm 0.5\end{array}$ & $\begin{array}{l}29.2 \pm 0.5 \\
19.2 \pm 0.1\end{array}$ & $\begin{array}{l}43.5 \pm 0.7 \\
27.2 \pm 1.4\end{array}$ & $\begin{array}{l}53.8 \pm 0.9 \\
33.2 \pm 1.4\end{array}$ & $\begin{array}{c}42.4 \pm 1.5 \\
24.4 \pm 3\end{array}$ & $\begin{array}{l}58.1 \pm 9.2 \\
31.3 \pm 3.2\end{array}$ & $\begin{array}{l}73.2 \pm 9.2 \\
38.2 \pm 3.3\end{array}$ \\
\hline
\end{tabular}

${ }^{\mathrm{a}}$ NNMR: neonatal mortality rate, ${ }^{\mathrm{b}}$ IMR: infant mortality rate, ${ }^{\mathrm{c}}$ U5MR: under-5 mortality rate 

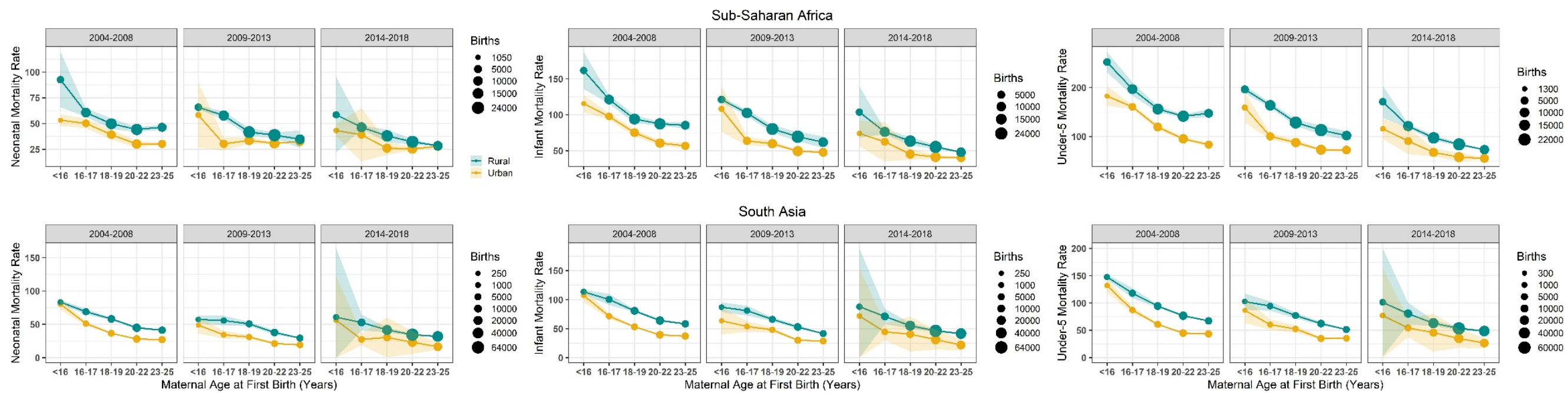

Figure 1. Neonatal (left), infant (center) and under-5 (right) mortality rates and their sampling errors within each age group and urban (yellow)

and rural (green) locations in SSA (top) and South Asia (bottom) by 5-year time period; 2004-2008, 2009-2013, and 2014-2018. The circle size represents number of births within each group. 

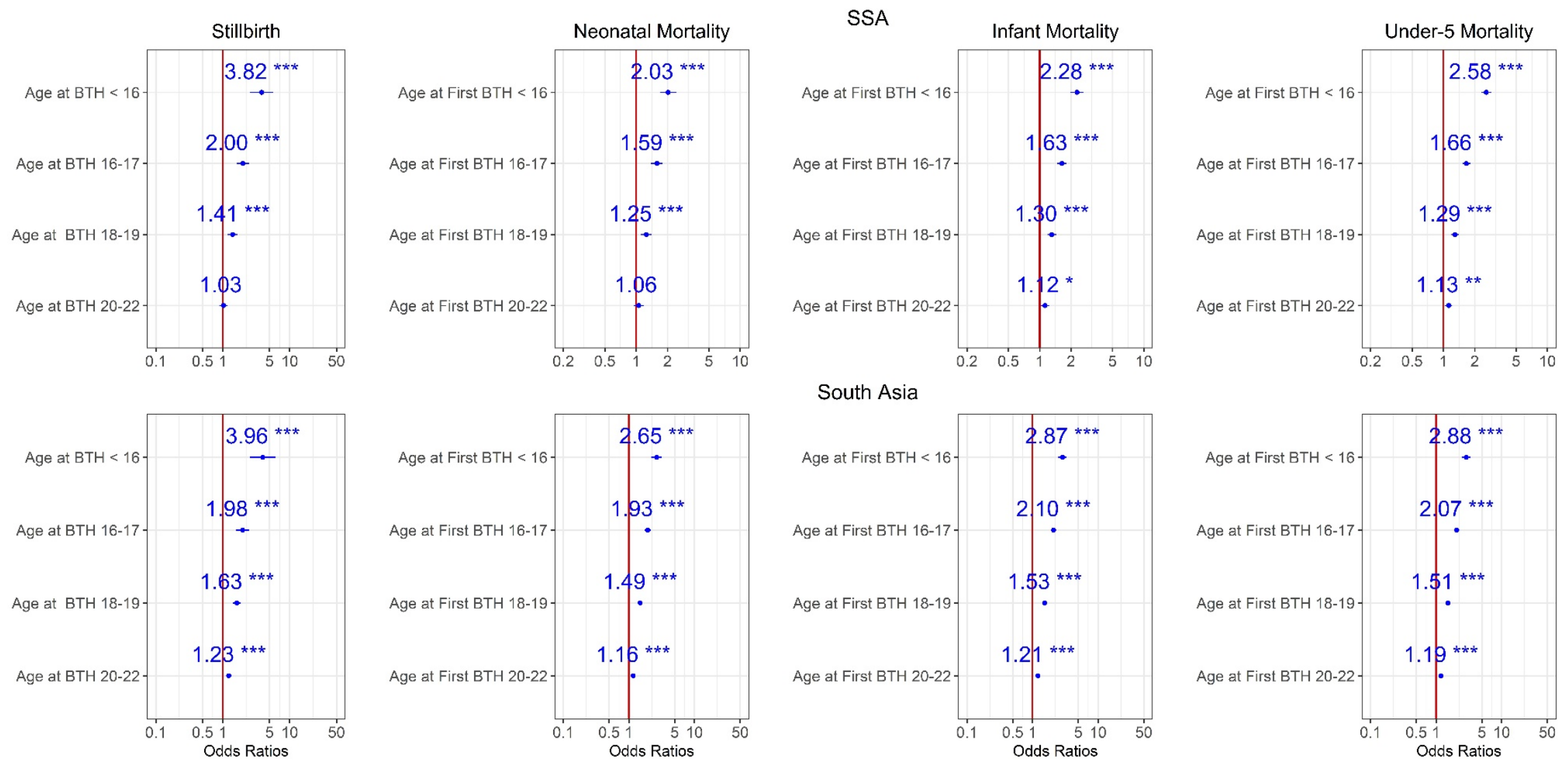

Figure 2. Ratios associated with neonate, infant, child, 1-59 months, under-5 years, and stillbirth in SSA and South Asia for the 2014-2018 survey period. Risk factors reducing the probability of death have odds ratios lower than 1 to the left of the vertical red line. Odds ratios (blue points), 95\% confidence intervals (horizontal blue lines) are given. P-values are shown with the asterisk signs (“***’ 0.001 ‘**’ 0.01 ‘*’ 0.05 ‘.’ 0.1 ' ’ 1 ).

Reference group is mothers aged 23-25 years old (Model 0). 

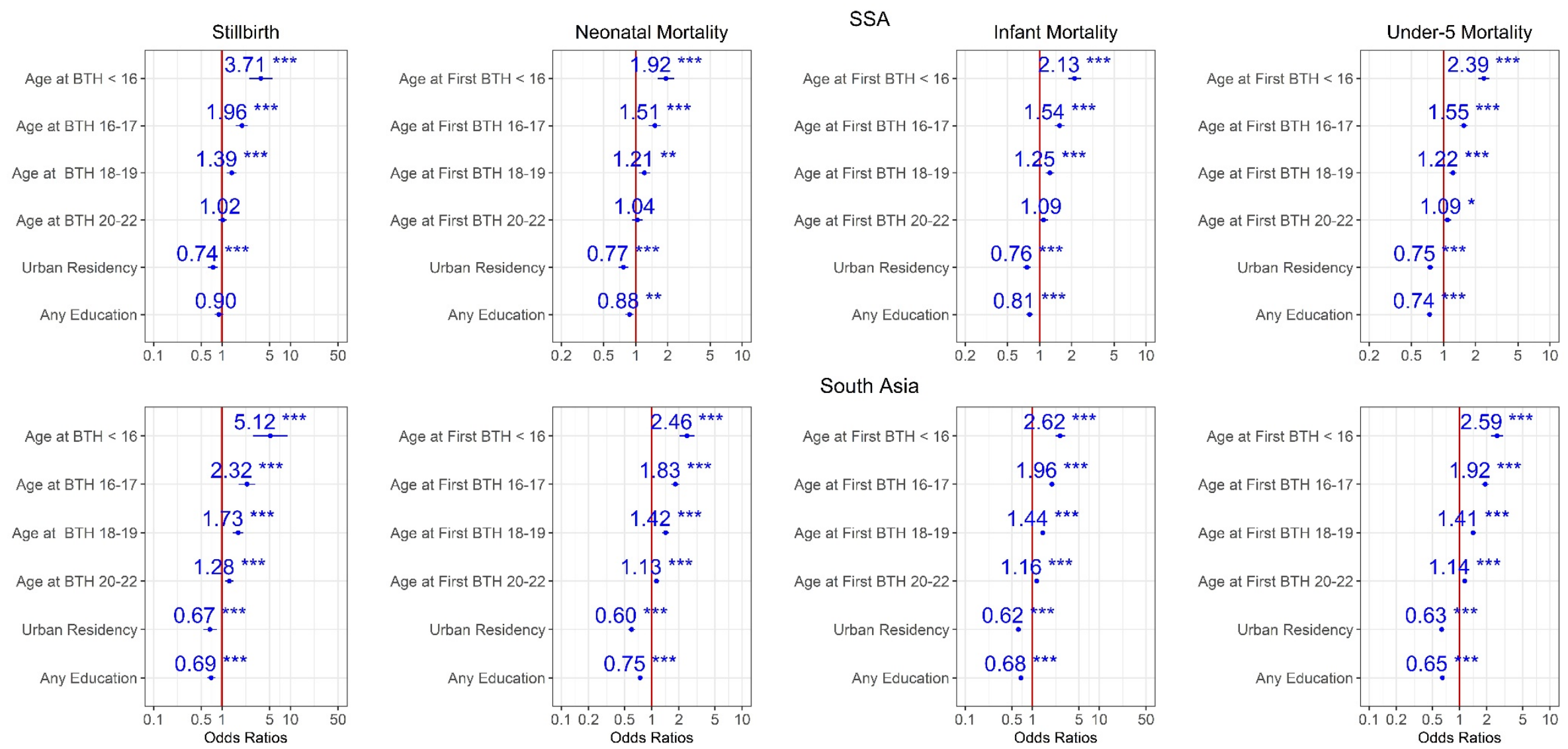

\section{South Asia}
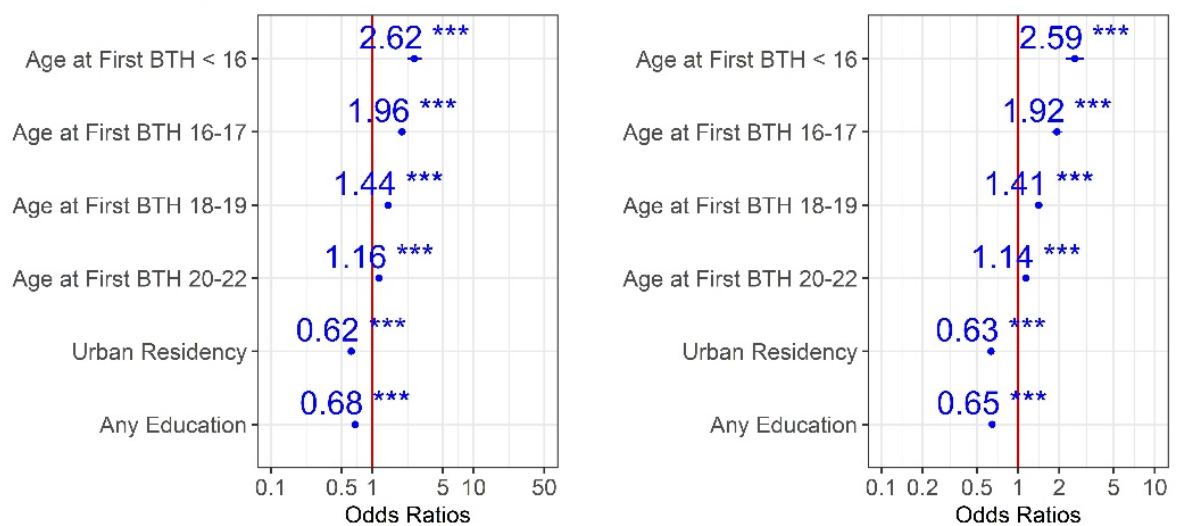

Figure 3. Ratios associated with neonate, infant, child, 1-59 months, under-5 years, and stillbirth in SSA and South Asia for the 2014-2018 survey period. Risk factors reducing the probability of death have odds ratios lower than 1 to the left of the vertical red line. Odds ratios (blue points),

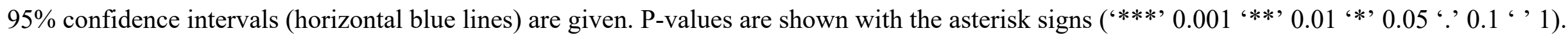
Reference group is mothers aged 23-25 years old who live in rural areas and have no formal education (Model 1). 

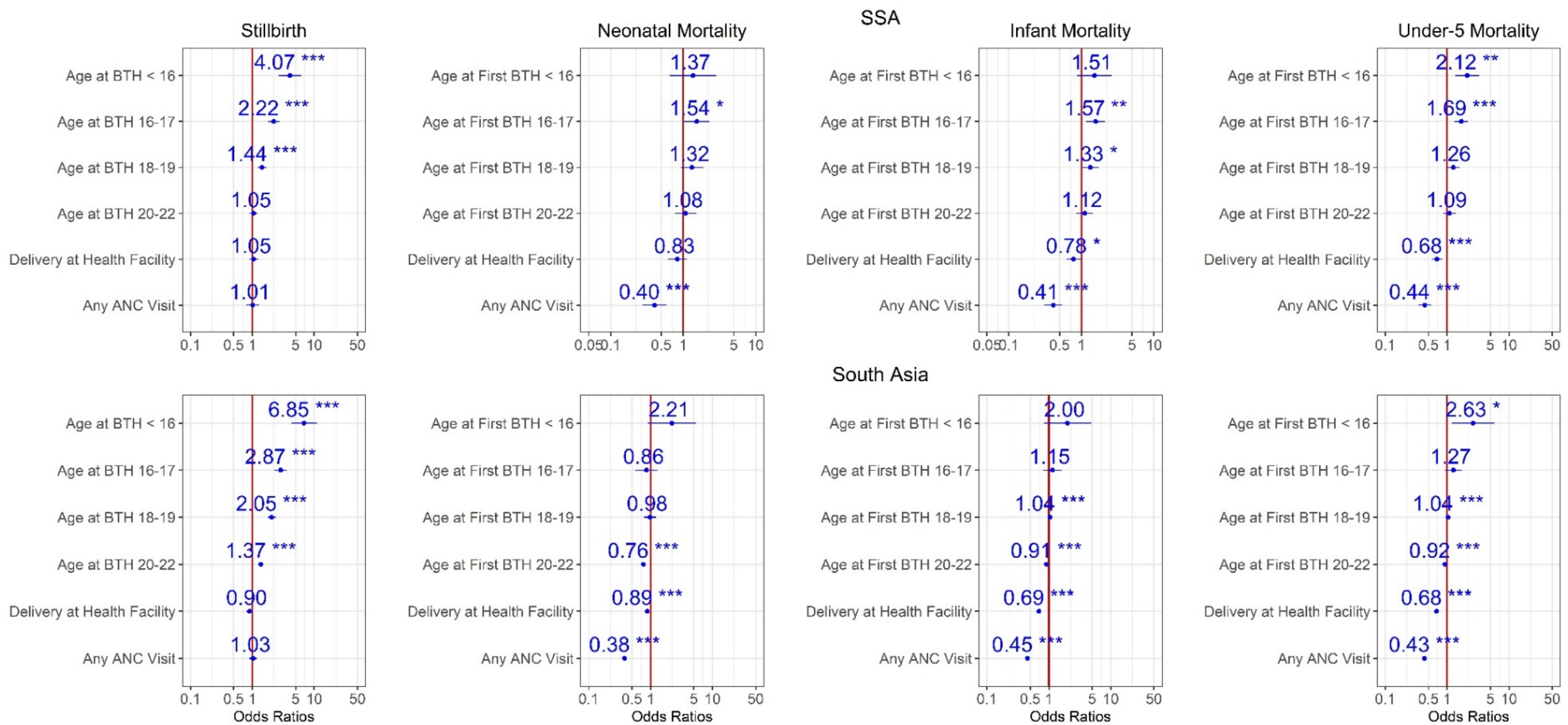

Figure 4. Ratios associated with neonate, infant, child, 1-59 months, under-5 years, and stillbirth in SSA and South Asia for the 2014-2018 survey period. Risk factors reducing the probability of death have odds ratios lower than 1 to the left of the vertical red line. Odds ratios (blue points), 95\% confidence intervals (horizontal blue lines) are given. P-values are shown with the asterisk signs (“***' 0.001 '**' 0.01 ‘*’ 0.05 '? 0.1 ' ' 1 ). Reference group is mothers aged 23-25 years old who delivered at home, and had no ANC visit (Model 2). 